Tălpaș, M. (2016). Words cut two ways: An overview of the situation of Afghan interpreters at the beginning of the 21st century. Linguistica Antverpiensia, New Series: Themes in Translation Studies, 15, 241-259.

\title{
Words cut two ways: An overview of the situation of Afghan interpreters at the beginning of the 21 st century
}

\author{
Mihaela Tălpaș \\ Babes-Bolyai University, Cluj-Napoca, Romania \\ talpas_mihaela@yahoo.com
}

This piece of research attempts to highlight the role of interpreters in the period 2001-2015 when international coalition forces were in Afghanistan during and after the war. The scope of this paper is, therefore, to address the risks faced by interpreters working for the coalition in Afghanistan in order to develop possible strategies for interpreters and the users of their services for tackling future similar situations of armed conflict. It should be mentioned that the interpreters themselves were perceived as a danger both by the very same coalition forces and by the local community. Consequently, the "dangerous interpreter" became a danger in itself for local interpreters. Having analysed a corpus of online interviews and articles, specialised journals, reports and literature containing the opinions and experiences of interpreters in Afghanistan and of other parties they interacted with, I shall try both to outline the risks faced by interpreters and indicate the necessity of having interpreters in the field. To this end, I shall outline the image of the interpreter-soldier by drawing attention to the risks faced by military personnel and drawing a parallel with those to which interpreters in Afghanistan are exposed. My aim, on the one hand, is to highlight the human side of the interpreter and, on the other, to create a more comprehensive image of "war interpreters at war", in order to deal better with the challenges of armed conflict in the field of interpreting, both as an interpreter and as a user of interpreting services.

\section{Interpreting conflict}

Given the legacy of our treatment of the Iraqis and Afghans that believed in us enough to help us, a legacy that amounts to bureaucratic abandonment, why on Earth would anyone want to step forward to help us in the future? If siding with the United States becomes seen as a death sentence, we better develop the most multilingual and multicultural military on the face on the planet, because we're not going to be able to rely on much help in the next war (Kemsley, 2014, para. 58).

Armed conflicts are becoming increasingly present on the international political, economic and social scene. Languages are the motor that creates 
the tension known to the parties directly concerned and also to indirect third parties. If they did not understand one another, then conflict would still be possible, but not its resolution, because no one would know what the other is aiming at. It would simply be a dialogue of the deaf. Fortunately, there are interpreters who can contribute to solving conflicts; yet, less fortunately, interpreters are also those who make conflict possible.

Nonetheless, in this paper I am not aiming to make a moral evaluation of the interpreter's role. I simply want to outline some of these roles, bearing in mind the belief that "guns destroy, but interactions can build" and that "firepower alone cannot save the day" (Brough, 2015). Moreover, I wish to place emphasis on the human nature of Afghan interpreters.

There is literature on the professional implications of interpretation, yet we should not forget that interpreters are not machines, even if there have been (hitherto unsuccessful) attempts at replacing the human factor in interpretation. Thus, if we are to aim at quality interpretation under extreme conditions, such as those in Afghanistan, we should first analyse the human weaknesses of the interpreter in order to develop mechanisms to mitigate their effects and attain good-quality performances.

I started by analysing conflict in a general sense and later on focused on armed conflict. I then moved on to pointing out the risks and downright dangers to which Afghan interpreters are subjected by drawing a parallel with the risks faced by soldiers, given that interpreters are often asked to perform related tasks which fall outside their normal responsibility. Consequently, I concentrated more on context-related military, natural and socio-cultural risks rather than on interpreting-related ones.

After that, I gave a thought to the role of interpreters as cultural and religious mediators. This role is paramount in a country where society itself is built on these two pillars. I convinced myself of this reality when I considered the descriptions provided by an American veteran who worked with interpreters in Afghanistan compared to those of other platoon leaders in a similar situation. The importance of interpreters was illustrated by concrete examples of instances when they acted as mediators in the interactions between local Afghans and foreigners.

\section{What is conflict?}

First of all, a clarification of the general term conflict is necessary, followed by a definition of armed conflict, as a particular instance of the former. This I feel is necessary, given that the situation I wish to study, namely that which has affected Afghanistan since 2001: intense armed conflict.

For general conflict, the definition given by the Berghof Foundation (2012) was considered. It states that 
[a] conflict is a clash between antithetical ideas or interests - within a person or involving two or more persons, groups or states pursuing mutually incompatible goals. Like all social phenomena, conflicts are usually complex and may emerge on different levels. Some are primarily intra-personal, while others are inter-personal, and there are conflicts across all layers of society. (p.10)

In other words, generally speaking, a conflict is a matter of choice that has to be made by a particular individual in a given context and bearing in mind several factors: context, people involved, emotional implication vs neutrality, physical and mental constraints etc.

One classification of conflict is that made by Tang (2007, p. 137), who points out that there are several types of cross-cultural conflict cultural, social and ideological - and these can vary from the level of isolated incidents to an open war.

The first distinction Tang makes is that between soft and hard conflict. A soft conflict is one in which the displeasure caused to the receiver of a translation or an interpretation is not made known to others or, if this occurs, then the result is not serious enough to trigger any formal measure. A hard conflict, on the other hand, involves a vociferation of the negative sentiment, the reaction extending from individuals to members of social groups or powerful institutions.

The likelihood of soft conflicts is higher in the translation of literary, academic or legal texts as well as in audiovisual, advertising and practical documents such as travel brochures and manuals for electronic products. According to the relationship between cultures - subordination or dominance - concessions may or may not be made and attempts will be made to solve the conflict. In contrast, there is a higher occurrence of hard conflicts in the context of international affairs and diplomatic events, when translation or interpreting can lead to "ill-grounded hostility towards and misconception of another country or an immigrant community as an enemy or adversary" (Tang, 2007, p. 137). In such a context, opposing political and/or ideological views or economic and/or social interests meet and the translator or interpreter may be tempted to intervene and water down declarations or formulations, which comes into contradiction with his/her neutrality and re-opens the question of "in-betweeners" vs "bridgebuilders".

Another classification of conflict is that made by Cheldelin, Druckman and Fast (2003, p. 29), who distinguish between intrapersonal, interpersonal, intragroup and intergroup conflict. Thus, intrapersonal conflicts appear at the level of an individual's predispositions, thoughts, ideas, drives and emotions and are the expression of an inner tension. In the case of an intrapersonal conflict, an interpreter is sometimes faced with a two-way exit: morality, according to personal beliefs, and professionalism - adhering to a professional code of ethics. Peter Less, an interpreter at the Nuremberg Trials, who had to interpret for those 
responsible for the deaths of his family, is a living example of an interpreter able to divorce personal opinion and duty. Although he admits that it was not an easy task, he adds that "you could not let your feelings interfere with your job" (Gesse, 2013, para. 45).

Interpersonal conflicts occur between individuals. At the moment of interpreting, we can be met with conflicts between the interpreter and one of the parties for which he or she works, conflicts between the interpreter and third parties, conflicts between the parties themselves or even conflicts between different interpreters, owing to incongruous opinions as to possible variants of interpretation.

Intragroup conflicts, as conflicts occurring between members of the same group, may seem to resume in a way the interpersonal type of conflict does, yet in this case the focus is on the dynamics of the group rather than on individuals taken separately. The general views and group ideology are of particular importance, with any particular imbalance causing tension within the group.

Intergroup conflicts appear between groups and, depending on the dimension and nature of the group (ranging from peaceful, almost "invisible", to extremist, even terrorist), their mediation requires a greater effort, often with the need for high-level official intervention.

\section{Armed conflict}

"In situations of intense conflict, translation becomes a war zone in its own right" (Baker, 2010, p. 128, my emphasis).Such a war zone is the Afghan theatre of war, in which numerous clashing factors are involved and which puts the interpreter in the situation of dealing with a particular case of conflict, namely armed conflict. From this point we shall assess the presence of interpreters in Afghanistan, a zone of armed conflict.

According to the Uppsala Conflict Data Program,

an armed conflict is a contested incompatibility that concerns government and/or territory where the use of armed force between two parties, of which at least one is the government of a state, results in at least 25battle-related deaths in one calendar year (Melander, online course material, emphasis added).

The apparent lull that characterised Europe's international relations at the end of the 20th century and the beginning of the 21stwas based on dialogue and co-operation across borders by means of common institutions. Nonetheless, it was short-lived; the events of 9/11 shook the international community to the core and reignited conflicts with parts of the world that had seemed so distant before, among them the Middle East, in particular Iraq and Afghanistan. In fact, between 1990 and 2000, 56 major armed 
conflicts took place in 44 different areas across the globe, most of them between 1990 and 1994 (Harabagiu, 2009).

Harabagiu (2009) shows how this foment and, in particular, the World Trade Center (WTC) attack which took place on 9/11,made evident the fact that armed conflict had undergone mutations and that military intervention was no longer sufficient to ensure security, given global interdependency and new risk factors.

Differently put, the human element should not be seen only as a means of destruction, but also as a peace-building instrument, valid for translators and interpreters alike. The United States did think of the benefits of having professional linguists in the field, but it failed to envisage the consequences of a lack or misuse of trained translators and interpreters.

This is to say that interpreters were seen as necessary but not as useful, at least not by the authorities; those who collaborated directly with them - soldiers, press agents, relief organisations - were of a different opinion.

The cost to the West was the loss of two wars - in Iraq and Afghanistan - which is understandable because, after all,

"[h]ostilities on the battlefield are not only a confrontation of forces and means, but also one of human intelligence, which makes military actions dynamic, violent, tense and determined" (Mazere, 2009, p. 73, my translation).

Among the new challenges to which human intelligence has to respond are ethnic tensions, local political instability and terrorism - the very ingredients that have characterised the situation in Afghanistan during the past 14 years (Harabagiu, 2009; Pentilescu, 2009). The problem is that "[i]n most cases, it [the reaction to terrorism] addresses the effects and not the causes" (Pentilescu, 2009, p. 110, my translation).

In the Report of the Joint Inquiry into Intelligence Community Activities before and after the Terrorist Attacks of September 11, 2001 (2002), this poor allocation of resources is evident at the level of linguists (un)available in languages such as Arabic, Farsi, Urdu and Pashto. These suddenly turned out to be of the utmost interest to the United States and to the coalition forces in general. The conclusion to be drawn from this is that, when the war in Afghanistan broke out, the United States was only $30 \%$ ready to cover the linguistic needs related to terrorism. While a "pool of interpreters" to be mobilised in intelligence gathering and analysis was deemed to be necessary, statistics cited by the report show that, in 2002, one year after the beginning of war in Afghanistan, only six degrees in Arabic were granted to individuals in the United States.

Undoubtedly, these linguistic resources were insufficient if we are to think that, according to the same Report of the Joint Inquiry(2002, summary 1) in June 2001, the number of troops or "boots on the ground" stationed in the US Central Command region, which also includes 
Afghanistan and Iraq, was 26,000. (Belasco, 2009, p. 4). In Fiscal Year (FY) 2002, in Afghanistan alone there were 5,200 US soldiers. The numbers rose to 20,400 in FY2006 and were expected to reach 63,450 troops in FY2009.

It is obvious that the international forces had to find interpreters and translators elsewhere. They were either local Americans who had learned Arabic - quite a few in numbers - or foreign students who had been to university in the United States. In addition, there were Muslim emigrants to the West or even Turkish mercenaries and other locals, most of them subcontracted by American companies (Guidère, 2008).

This random selection of interpreters led to several problems related to quality, loyalty and even discrimination on the part of the employer and of the beneficiary state; many camps had no interpreter or translator at all (Ross, 2004) or, if there were translators or interpreters, then the ratio of interpreter to number of troops served was very low (one for every 150, on average) (Guidère, 2008, p. 17).

\section{The risks for interpreters}

The Afghan interpreters performed several roles, not only interpreting, when military units to which they were assigned required them to perform the additional tasks of journalists, soldiers, intelligence-gathering officers and scouts (Guidère, 2008).

It is why, as stated at the beginning of this article, I shall outline the challenges - the risk and dangers - Afghan interpreters were faced with. Moreover, my aim is to indicate a series of risks that are normally associated with soldiers and to see to what extent they apply to Afghan interpreters. In this way I wish to justify the concept of interpreter-soldier, which I deem more appropriate in designating the working conditions of Afghan interpreters.

\subsection{Context-focused risks}

The presence of foreign troops in Afghanistan poses a set of risks and threats for the troops themselves, for the local population and for any collaborator with the coalition, including the interpreters. The United Nations Office for Disaster Risk Reduction defines "risk" as being "[t]he combination of the probability of an event and its negative consequences" (2007, online terminology).

According to Pah, a colonel in the Romanian army, "[a] risk is an attitude towards a danger or a threat. It is assumed, imposed, associated, consciously, responsibly or, on the contrary, randomly, collaterally, untimely" (Pah, 2009, p. 102, my translation). We have highlighted the word "assumed" because these interpreters, even if at the beginning they 
did not anticipate what course their job would take, at some point, when they acknowledged the dangers they exposed themselves to, they faced these dangers by conscious decision ("Johnny Walker", online video interview). Such risks, which are various and complex, can manifest themselves at any time and in any place.

In relation to multinational military operations, Pah identifies three categories of threat: military, natural and social (Pah, 2009).

\subsubsection{Military risks}

Among the military risks there is the existence of enormous quantities of weapons, explosives and ammunition, owned by the Taliban, who use them against the local population and the coalition forces. They do it especially during religious rituals, in the case of locals, or during military or logistic and humanitarian missions, as far as the coalition and its collaborators, including interpreters, are concerned. Isolated subunits and command centres are also targeted, but improvised explosive devices (IEDs) also represent a great threat (Pah, 2009).

In this context, it is no wonder that the toll on Afghan interpreters is "hideously high" (Anderson, 2014, p. 7). Until the FY 2008, private companies hiring interpreters were not required to register their deaths. Even so, The List Project to Resettle Iraqi Allies estimates that, in the case of Iraq alone, the number of casualties was roughly 1,000 (Kemsley, 2014).

According to Kemsley (2004), others consider the numbers even higher, given that a leaked list from one of the contracting companies mentioned 300 names. There were over 100 such companies, so casualties should have increased proportionally.

These numbers refer to the United States alone. Casualties were lower in number in the case of the United Kingdom, but still high. Concerning Iraqi civilian interpreters, the estimates point to 250 being killed during the conflict, which means a hundred times more than the toll among British soldiers (Baker, 2010, pp. 206-207).

There is a scarcity of data related to Afghan personnel. A representative of the British Ministry of Defence said that, since 2001, approximately 3,800 civilians had worked for the British forces, though it is not known how many of them were interpreters (Engelhart, 2015).

In any case, interpreters were asked to accompany soldiers on all their missions, irrespective of the risks involved, without being provided with the same degree of protection. For example, Rafi, an Afghan interpreter for the British forces, was in a car blown up by an IED. He survived, but had been ill-equipped: "a piece of cloth and one small plate to protect my heart" was all he had at his disposal, whereas the British soldiers had full body armour (Engelhart, 2015).

Srosh, another Afghan interpreter, who served the US forces, said he was allowed to carry and fire weapons. He also indicated that: 
All of the patrols were walking patrols, so I had to patrol with them day and night. Like three days, four days, we were walking for 24 hours or 72 hours and only eating one MRE [meal ready to eat] and we didn't have any training like the Marines. We were not professional. We faced ambushes and IEDs. (Anderson, 2014, p. 9, my emphasis)

He pointed further to the fact that interpreters were not trained fighters, but had to walk, rest, eat and fight like them, apart from providing linguistic and cultural mediation. Cases similar to his are myriad, some luckier than others (Anderson, 2014, p.9; Bradley, 2014).

\subsubsection{Natural risks}

In the natural risks category Pah (2009) refers predominantly to weather conditions and to the terrain. Temperatures can rise to over $45^{\circ} \mathrm{C}$, which, added to storms of sand and to heavy rain during the rainy season, can be a serious obstacle to the troops and their accompanying interpreters. Then there is the broken terrain and hidden access paths, often known only to the insurgents, not to mention the local dangers represented by the dangerous animals such as vipers, cobras, spiders (including venomous spiders) peculiar to that particular area.

In this case, the interpreter is more of a cultural mediator, his/her role being that of counselling his/her unit on which road to take for a particular mission, which itinerary to avoid, whom to address for a given request and so on. Only afterwards does the actual interpreting begin, but even then the distinction between pure interpretation and mediation is quite hazy, even hazier than in a "normal" interpreting situation. But we shall learn more about it when talking about the roles of interpreters in Afghanistan.

\subsubsection{Social risks}

The third category of risks mentioned by Pah (2009) is social. He links this with the local population, though we feel that foreign, intervening forces should also be considered to be social risks. On the part of the locals there are several factors which account for social risks: first, a low rate of literacy (approximately 40\%) among the Afghan population, which means the people can be manipulated by the Taliban; secondly, the Islamic faith, which is the religion of $95 \%$ of the population and which entails specific holidays, traditions and customs, and, thirdly, people's lifestyles (the way they eat, dress, talk, do business etc.).

One interpreter claims: "The problem is that we have lots of uneducated people. They just think that if someone works with Americans 
he is a spy, he is not good, and should be killed" (Anderson, 2014, p. 10). Given this background, there can be clashes between locals and foreigners that can take the form of different, often uncontrolled reactions: religious fanaticism, emotional instability, even aggression and treason (Pah, 2009).

Pah (2009) even mentions attempts on the part of local insurgent groups to recruit members from among the local administration, the local security forces or even from within the coalition, the interpreters being an ideal target group because they know a lot of confidential information.

If the insurgents fail to make the interpreters join their ranks, then, according to the 2010 Taliban code, cited by the United Nations Assistance Mission in Afghanistan (UNAMA), "the infidel's translators" should receive the death penalty (Engelhart, 2015). This threat is far from being merely empty words; online videos of filmed executions are striking evidence.

Thus, the conclusion is that "estimating the risks and threats characterising today's theatres is an art rather than a science; it mostly depends on the lessons learned from previous incidents, events and situations, on intuitive analysis and, lastly, on personal experience" (Pah, 2009, p. 107, my translation).

\section{Usefulness of Afghan interpreters}

If we set off in pursuit of quality, we see that there is no good performance across the board; it is simply the difference between expected and actual service. Quality is in fact a matter of need but, in an armed-conflict situation, this need is subject to special conditions, which make it harder to fulfil.

I shall accordingly change tack and, instead of analysing the quality aspect, we shall ask different questions based on the concept of need, namely: Are interpreters part of that need? Are they necessary in the Afghan theatre?

After analysing the linguistic situation for foreign troops in the field as well as their praise of their interpreters' work, my conclusion is that, yes, interpreters are necessary, and we shall see why by illustrating their roles.

Palmer (2007, p. 13) encompasses the role of the interpreter within a "continuum of possibilities", from a mere intermediary who enables "the transparent transition of information from one language to another" to a cultural mediator. It is on this latter dimension that I shall linger more by turning my attention to the Afghan case and give factual examples. 


\subsection{Interpreting culture and religion}

In the previous section, we listed social risks among those with which Afghan interpreters are confronted. This category also comprises cultural and religious risks. These have to be toned down in order to ensure the success of a military mission (Cruceru \&Ifrim, 2009). According to these two authors, culture represents all the knowledge, beliefs and behaviours which are passed down to future generations to form the general characteristics of a racial, religious or social group. As for religion, it is a transcendent phenomenon, different from one group of people to another and across epochs; it marks the voluntary spiritual bond between divinity and the human being and has three essential components: doctrine, morality and cult.

In some theatres, the fusion between culture and religion is so strong that it creates social norms, rules, attitudes and behaviours. These are valid not only for the local population, but also for foreigners, lest strong cultural clashes occur. Therefore, it is advisable that foreign military interventions be aware of religious symbols, celebrations or manifestations, which may offend the locals and compromise the mission (Cruceru \&Ifrim, 2009).

This is where the interpreter intervenes as a cultural mediator. Such was the example of an interpreter working for a group of Dutch soldiers in Afghanistan. At one point, some of them forced their way into a mosque, scattered pieces of the Quran and started singing and dancing. The Afghan National Army (ANA) soldiers were outraged and threatened to stop collaborating with the international coalition if such an incident happened again.

The interpreter stepped in, accompanying some of the ANA soldiers back to the mosque, where they put everything in order and tried to explain that it had been a mistake, since the Dutch soldiers had not known that it was the Quran they were throwing around, as they did not know the language. On the other hand, the interpreter made the soldiers promise that they would not behave so recklessly in future. The Afghan soldiers were appeased and a more serious confrontation was avoided thanks to the mediation of the interpreter (Hoedemaekers \&Soeters, 2009, p. 343).

Gestures, attitudes, behaviour and verbal and non-verbal ways of expression, which seem completely natural and harmless in Western culture, can backfire and trigger violent reactions in other societies. It is enough to say that the Middle East is a true Tower of Babel, with numerous languages and dialects, such as Arabic and Kurdish in Iraq, Pashto and Dari in Afghanistan, Farsi in Iran, Urdu, Pashto, Sindhi, Punjabi and others in Pakistan. Moreover, accents and speaking particularities are essential tools in differentiating between locals belonging to particular ethnic groups (Guidère, 2008). Thus, easing the interactions between local civilians and military staff is to the credit of Afghan interpreters. 


\subsection{Interpreters - narrated narrators}

On the US Army webpage for job openings there is a job offer for an interpreter or translator who is able to speak one or several Arabic dialects, amongst which Pashto-Afghan, Persian-Afghan (Dari), Persian-Iranian (Farsi), Arabic-Gulf-Iraqi and others are listed.

The first thing we notice is that no distinction is made between the profession of an interpreter and that of a translator. They are formally listed separately, which should account for recognition of the differences between the two. Yet, in practice, given that only one person performs both tasks, the distinction is not respected.

In point of fact, among the duties which befall the interpreter/translator the job opening lists the following: to "prepare nontechnical translations into the target language and perform sight translations from a target language into English", to "assist military contracting officers with local purchases" as well as to "provide interpretation support at military traffic control points and local media events". We have highlighted the term "local media events" because it demonstrates the fact that interpreters do not only interpret and translate, but also act as "unofficial historians" (Baker, 2010, p. 214).

In other words, interpreters are not only narrated in the media, but they also become narrators themselves and often turn from fixers (the name given by journalists to their interpreters) into proxy journalists. In certain situations, often when it is too difficult for Western journalists to go into the field and conduct interviews, it is the translator/interpreter or fixer who does it. It is even possible for the fixer to choose the interviewee, based on his/her knowledge of the people in the community (Palmer \& Fontan, 2007, p. 10, p. 12).

Fixers are also those who compile special reports on events that are too dangerous for foreign journalists to become involved in. This raw material later becomes working material for foreign media, which means to say that fixers become "effectively journalists". The Guardian is illustrative of this phenomenon: it turned an ex-fixer from Iraq into a fulltime correspondent (Palmer \& Fontan, 2007, p. 10, p. 12).

One explanation has to do with the safety risks that foreigners run, but also with the fact that troops, staff, journalists and non-governmental organizations (NGOs) are constantly replaced. As Blake Hall, a former captain in the American army, said in an interview, soldiers know that they can serve 15 months or more in Iraq or Afghanistan, and then they can go home, whereas interpreters do not have that certitude; they are there to work but they do not know for how long (The Take Away, 2013, online interview).

Thus, narration of and by interpreters is part of the image that people - especially those who are outside hotspot areas - have of the reality in Afghanistan. Moreover, this narration generates different opinions that form the basis of decision-making. 


\subsection{Interpreters - cultural mediators}

In another advertisement for a job as an interpreter offered to Afghans or third-country nationals residing in Afghanistan, a small private company in Massachusetts was looking for part-time/periodic to full-time Afghan Pashto/Dari interpreters "in support of implementing, assessing, and monitoring U.S. grants and programs throughout Afghanistan" (Torden LLC, n.d.).

This time, there is a specific requirement, aimed exclusively at an interpreter, not an interpreter/translator. Nevertheless, this apparent delimitation becomes lost once we go through the duties of the so-called interpreter. These include the following tasks: to accompany and translate for Kabul-based personnel on visits to ministries or on trips throughout Afghanistan; to translate Dari/Pashto government documents into English, and also to advise on cultural and/or regional issues (Brotman, 2014; Torden LLC, n.d.).

Not only is the interpreter expected to translate documents, but he/she also has to provide counselling to foreign personnel or, put differently, to act as a cultural mediator. Interpreters are therefore necessary in order to enable communication between different parties, both indigenous and external.

Baigorri-Jalón (2011, p. 180) explains how interpreters can be used at different stages: before armed conflict, during its development and after its settlement. He points to the role of the interpreter during the preparatory process (in diplomacy and intelligence gathering), during warfare (which includes contact with local civilians, propaganda, contact with prisoners of war, control of occupied forces, evacuation of noncombatants), at the end of hostilities (for armistice negotiation and signing, movement of populations, demobilisation, reconstruction of local societies etc.) and, at times, for settling responsibilities, which take the form of international trials.

Therefore, the interpreter is involved in the entire armed-conflict process. As such, it would be only natural that the interpreter should be a very well-trained professional who knows his/her tasks and the tasks of others and who knows how to make clear his/her responsibilities to those who are unaware of them.

The same advertisement mentioned previously makes reference to a "bachelor's degree in a related field" as a plus, not as an absolute requirement. In a normal situation and "in any other sphere of professional interpreting activity, it is [i]nadvisable to hire a young interpreter with no experience and no proper training. This is not the case in conflict interpreting, where the law of supply and demand rules" (Gómez Amich, 2013 , p. 17). In point of fact, "extreme" situations are such that they become real "schools for interpreters".

Baigorri-Jalón (2011) and Palmer (2007) give numerous examples of people who were forced by circumstances into becoming interpreters 
during historical events such as the Second World War, the Spanish Civil War or, more recently, the wars in Iraq and Afghanistan.

\section{4. "Use your interpreter"}

"Use your interpreter" is the piece of advice given by Captain Michael G. Cummings (2012, p. 44) to his fellow American platoon leaders who might serve in Afghanistan. His is a guideline about the collaboration between coalition forces and Afghan interpreters and in what follows I shall select some elements that highlight the role of the interpreter as a cultural mediator from the perspective of military personnel.

Cummings says his role and that of the coalition in general was to "influence the population", which he says with the conviction that "in a counterinsurgency, destroying is not as important as influencing" (Cummings, 2012, p. 43).

In the same vein, Cruceru and Ifrim (2009) agree that, in the light of armed-conflict mutations, winning the war has ceased to mean only the annihilation of the enemy, but also transforming civilians into allies in the theatre of war.

Nonetheless, in order to be able to influence the population, the coalition forces would have to be able to speak the language of the locals, which is seldom the case in Afghanistan. In comes the interpreter, who represents the "only connection to the Afghan population" (Cummings, 2012, p. 43, my emphasis). This only underlines Baker's (2006) statement that "there is no point in the U.S.A. declaring conflict on Iraq without ensuring that the Iraqis and the rest of the world 'hear' that declaration" ( $p$. 2).

Therefore, interpreters are presented as "your lifeline to Afghanistan" (Cummings, 2012, p. 43). Cummings makes a clear distinction between what he calls translating and actual interpreting, which he says are the two main roles of an interpreter. The former involves the simple rendition of a message from English into Pashto or Dari or vice versa, whereas the latter implies "phrasing [the message] as accurately and appropriately as possible".

Next, Cummings (2012, p. 43) gives a full list of the duties corresponding to interpreting, some of which have been mentioned previously in this paper. Among them are:

cultural advisor ("He is not just your mouthpiece or translator - he is your guide to Afghan culture");

- $\quad$ provider of subject-matter on Afghanistan ("An interpreter knows more about Afghan culture than you ever will");

- $\quad$ lie detector ("He'll probably pick up on cultural cues that you may miss");

intelligence source; 
- $\quad$ phone operator ("In most cases he will answer calls for you");

- $\quad$ interview organiser ("He can also set up meetings with locals");

- language teacher ("Your interpreter can also teach your entire platoon Dari or Pashto").

It is obvious that interpreters are not only useful in but are absolutely essential to any external intervention. Thus, Cummings makes several suggestions to military personnel who use interpreters. In the light of this advice, the interpreter crosses the frontier between interpretation and cultural mediation. Therefore, during meetings with locals, staff are encouraged to speak to the Afghan and not the interpreter, which should make clear the fact that the interpreter is only an intermediary (Cummings, 2012, p. 45).

Yet Cummings' following statements put more and more emphasis on the interpreter, who becomes a full cultural mediator. Thus, staff are advised to tell the interpreter to stop addressing a foreigner if what they are saying will offend the local recipient and to prompt the interpreter to ask for clarification when there are things he/she does not understand. The conclusion is to "treat your interpreter as if he were your own soldier" (Cummings, 2012, p. 44) and to ask for as many interpreters as the unit can afford.

\subsection{Learning from experience}

Generally speaking, a conflict is by definition an encounter between different ideas, interests and opinions. These differences are the more poignant if they belong to individuals with distinct cultural and social backgrounds and especially if the conflict dealt with is an armed one. Such is the case of the war in Afghanistan, fought by the coalition forces between 2001 and 2014 and its aftermath. The actors are locals, military personnel, NGOs, humanitarian organisations, mass media, interpreters etc. They are from distinct social groups or countries and, as a consequence, they are also holders of specific roles that bring with them contrasting situations.

Hoedemaekers and Soeters (2009, p. 339) have analysed the interaction between these forces in the Afghan theatre of war. Their subjects are approximately 90 local interpreters aged between 20 and 27, seven national interpreters - Afghans aged between 33 and 47 who had been living in the Netherlands for between 7 and 15 years - as well as the Dutch forces based at Camp Holland in TarinKoner in the province of Uruzgan, in January 2008, and who benefited from the services of these interpreters.

The authors focus on concepts such as embarrassment, trust, distrust, self-image, honour and politeness in the interactions between soldiers and interpreters, between soldiers and locals, and between locals and interpreters. Along these lines, they highlight the fact that in the Middle 
East losing face is "a serious and pervasive problem, more so than in the Western hemisphere" (2009, p. 330, p. 335).

Why? Because face goes hand in hand with the concept of honour, and also with the deeply ingrained belief that individuals are members of a group or a community. As a result, when an individual loses face, his whole family, clan or tribe loses its honour, and vice versa.

The role of the interpreter in the middle of these intertwining strings is to try to harmonise the different cultures in order to mitigate the results for all the parties involved. The interpreter can adopt three general approaches. First, he/she can be a mere translator, similar in a way to "machine translation", which provides a word-for-word rendition of the message. Secondly, he/she can be the author of the message, meaning that, within the frame of the original message, he/she intervenes at the level of form and adapts the text so as to make the message easier for the parties involved to understand. The third role is that of a principal and corresponds to fresh talk. In this last case, the interpreter speaks for him- or herself and even has the initiative to ask questions instead of interpreting the others' enquiries (Hoedemaekers \&Soeters, 2009, p. 341). This is the least recommended approach, yet, given the context of Afghanistan, there is always a mixture of the three.

There are countless instances of when the intervention of an interpreter succeeded, by means of cultural mediation, to avoid unsatisfactory results for one or all of the parties involved in a dialogue. At times, these initial tensions could even have degenerated into violence. We have seen the example with the Dutch forces, the Afghan National Army (ANM) and the violation of a mosque, but there are others too, such as certain gestures, the subject of religion and references to women and the elderly, as indicated below.

For example, a common mistake made by foreign soldiers is when they raise their thumb in appreciation of something positive. However, the meaning of this gesture is completely the opposite in Afghan culture, where it is seen as a provocation or an insult (Hoedemaekers \&Soeters, 2009, p. 339).

Religion is, as we mentioned before, a key element in an Afghan's life. It is therefore inappropriate for foreign soldiers or interpreters to say they do not believe in God or that they are not religious people (Hoedemaekers \&Soeters, 2009, p. 345).

Women are yet another sensitive topic. Women are not to be mentioned in a conversation, because they are part of the Afghan man's private life and, unlike in the West, a wife or a daughter is not a subject of discussion with foreigners. Even when they interview Afghan women, foreigners cannot look at the woman; her face has to be hidden. Here, female interpreters have to enter the scene. If there are none in the vicinity, then all sorts of tricks are used. One example is that of a male Afghan interpreter who covered his face when interviewing a local woman: he used 
only appellatives such as "sister" or "mother" when talking to her (Hoedemaekers \&Soeters, 2009, pp. 345-346).

It is also important to address the elderly, who are one of the founding pillars of Afghan communities, in a respectful way, using formulations such as "hajji" and not their name.

Metaphors are part of everyday discourse: at one point, one interpreter refers to a person with good behaviour by calling that person "a tree with fruit", whereas a disrespectful person would be "a tree without fruit" (Hoedemaekers \&Soeters, 2009, pp. 346-347).

This is not to mention the actual way in which conversation is made in Western culture compared to the norm in Afghan culture. In the former case, a discussion begins by simply stating the purpose and by presenting all the terms of the problem as a way of starting negotiations. On the contrary, Afghans always start their meetings with tea and some small talk and only then do they proceed to the serious business. They are more elegant in negotiating and try to avoid expletives. If an interpreter has to render such an expression, then he/she first apologises, making it clear that the words do not belong to him/her (Brotman, 2014; Hoedemaekers \&Soeters, 2009, pp. 346-347).

\section{Conclusion}

Conclusions are useful only if they help with understanding a certain situation in order to improve it and to develop strategies for dealing with similar instances in the future. In this sense, it is hoped that this paper will raise awareness about the presence and input of interpreters in armedconflict contexts.

For this purpose, this paper started by defining conflict from a general point of view and then focused on armed conflict. The armed conflicts of the end of the $20^{\text {th }}$ century and the beginning of the $21^{\text {st }}$ have suffered mutations: their aim is to conquer by soft means rather than by hard ones; and words, together with linguists, translators, interpreters and mediators, are such soft instruments.

The article continued with an overview of the risks faced by interpreters in armed conflicts. Its focus was on context-related risks, namely military, natural and social. The conclusion was that these risks are very similar, if not, at times, identical, to those faced by military personnel. They are related to geopolitical contexts, geographical location (with all the ensuing difficulties, such as terrain, natural hazards and living conditions), social constraints, linguistic needs, language resources, technical shortcomings, and logistical and administrative aspects. To make matters worse, these risks turn from being on-the-job to being out-of-thejob, which means they affect not only the professional interpreter but also the individual. 
In order to understand why this happens, the roles assumed by interpreters were considered, and it was revealed that they often performed additional tasks. Thus, interpreters became journalists, translators, language and culture teachers, soldiers, cultural mediators and, in some cases, even friends. Moreover, the interpreter seemed to be stranded between the expectations of the others - be they direct participants in the act of interpreting or third parties - and their actual performance, dictated as it is by both external and personal constraints.

Next, an analysis was presented of the advice given by a captain in the United States Army who collaborated with interpreters in Afghanistan and who summarised their multiple roles. His conclusion was that interpreters are the only link foreign personnel have with local populations and the local reality. Consequently, interpreters should be treated with due care and respect and should benefit from the necessary conditions to perform their job, taking into account any context-related limitations.

The article concluded by making a call for all concerned to learn from the experience of the armed conflict in Afghanistan in order to avoid repeating the same mistakes in similar situations in future. Given the current international scene, when it is enough to read the news headlines to discover a few major conflicts and some dozens of smaller ones across the globe happening on any one day, we feel that, unfortunately, there will still be occasions on which to put these lessons into practice.

\section{References}

Anderson, B. (2014).The interpreters. Published by VICE News. Retrieved from https://s3.amazonaws.com/vice_asset_uploader/files/1404757485The_Interpre ters_Ebook_v6.pdf (accessed 3 June 2016).

Baigorri-Jalón, J. (2011). Wars, languages and the role(s) of interpreters.In H. Awaiss\&J. Hardane (Eds.), Les liaisons dangereuses: Langues, traduction, interpretation (pp. 173-204). Beirut: Université Saint Joseph.

Baker, M. (2006).Translation and conflict: A narrative account. London: Routledge.

Baker, M. (2010).Interpreters and translators in the war zone: Narrated and narrators. The Translator, 16(2), 197-222.

Berghof Foundation (Ed.). (2012). Berghof Glossary on conflict transformation. Berlin: Berghof Foundation Operations.

Bradley, R. (2014). Heroes left to die. Retrieved from http://warontherocks.com/2014/04/heroes-left-to-die/\# (accessed 4 June 2015).

Brotman, B. (2014). Afgan interpreter finds refuge at Marine's home. Retrieved fromhttp:/www.military.com/daily-news/2014/12/26/afghan-interpreterfinds-refuge-at-marines-home.html?comp $=700001075741 \&$ rank $=5 \quad$ (accessed 7 June 2015).

Brough, M.-W. (2015). Translating trust in Iraq, one Arabic greeting at a time. Retrieved fromhttp://www.latimes.com/opinion/op-ed/la-oe-0301-broughiraqi-interpreters-20150301-story.html (accessed 9 June 2015). 
Cheldelin, S., Druckman, D.,\& Fast, L. (2003).Conflict: From analysis to intervention. London: YHT.

Connel, T. (2006). The application of new technologies to remote interpreting. Linguistica Antverpiensia New Series - Themes in Translation Studies, 5, 311324.

Cruceru, V. \& Ifrim, R. (2009). Cultura și religia - componente esențiale ale dimensiunii civile în operațiile militare. Revista forțelor terestre, 1(2), 115126.

Cummings, G. M. (2012). Influencing the population: Using interpreters, conducting KLEs, and executing IO in Afghanistan. CALL Newsletter, 12-18, 43-51.

Engelhart, K. (2015). The Afghan interpreters facing Taliban death threats are taking Britain to Court. Retrieved from https://news.vice.com/article/the-afghaninterpreters-facing-taliban-death-threats-are-taking-britain-to-court (accessed 4 June 2015).

Gesse, T. (2013).Lunch with a legend. Retrieved from http://aiic.net/page/1665/lunchwith-a-legend/lang/1 (accessed 9 May 2016).

Gómez Amich, M. (2013).The vital role of conflict interpreters. Nawa Journal of Language and Communication,7(2), 15-28.

Guidère, M. (2008).Irak in Translation : De l'art de perdre une guerre sans connaître la langue de son adversaire. Paris: Éditions Jacob-Duvernet.

Harabagiu, P. (2009). Mediul internațional de securitate - tendințe și perspective. Revista forțelor terestre, 1(2), 77-85.

Hoedemaekers, I.,\&Soeters, J. (2009). Interactions rituals and language mediation during peace missions: Experiences from Afghanistan. In C. Giuseppe (Ed.), Advances in military sociology: Essays in honour of Charles C. Moskos, Part $A$ (pp. 329-352). Bingley: Emerald.

"Johnny Walker"- Iraqi Translator Worked With Navy Seal In Iraq - Huckabee. (2014). Video material retrieved from https://www.youtube.com/ watch? $\mathrm{v}=\mathrm{DWxDQu} 82 \mathrm{~N} 04$ (accessed 25 April 2015).

Report of the Joint Inquiry into Intelligence Community Activities before and after the terrorist Attacks of September 11, 2001 - by the House Permanent Select Committee on Intelligence and the Senate Select Committee on Intelligence.(2002).Retrieved from http://fas.org/irp/congress/2002_rpt/ 911rept.pdf (accessed 11 December 2015).

Kemsley, T. (2014).Fleeing ISIS: The story of an Iraqi interpreter left behind. Retrieved from https://medium.com/@tamarranicole/fleeing-isis-the-story-of-an-iraqiinterpreter-left-behind-3e13fe42d1b8 (accessed 4 June 2015).

Krane, J. (2005). The most dangerous civilian job in Iraq. Dozens of translators for U.S. military have been killed. Retrieved from http://www.nbcnews.com/ id/7911356/\#.UVaaPpbTBUp (accessed 7 June 2015).

Mazere, T. (2009).Mutații cantitative și calitative în conflictele majore ale secolelor. Revista forțelor terestre, Anul I, Nr.2, 69-76.

Melander, E. (2015). The UCDP Armed Conflict Definition. Retrieved from $\mathrm{http} / /$ www.undp.org/content/dam/norway/img/sdg-16-oslo-2016/Erik\%20 Melander.pdf (accessed 7 July 2016). 
Pah, P. (2009). Considerații privind principalii factori de risc la adresa forțelor coaliției și a populației locale din teatrele de acțiuni militare. Revista forțelor terestre, Anul I, Nr.2, 101-108.

Palmer, J \& Fontan, V. (2007). Our ears and our eyes. Journalists and fixers in Iraq. Journalism, 8(1), 5-24.

Palmer, J. (2007). Interpreting and Translation for Western Media in Iraq. In M. Salama-Carr(Ed.), Translating and interpreting conflict (pp. 13-28). Amsterdam-New York: Rodopi B.V.

Pentilescu, I. (2009). Terorism, acțiuni și reacții. Revista forțelor terestre, Anul I, Nr.2, 109-114.

Ross, B. (2004). Reservists Face Charges in Iraqi's Death. Retrieved from http://abcnews.go.com/WNT/story?id=131660\&page=1 (accessed 25 April 2015).

Tang, J. (2007). Encounters with Cross-cultural Conflicts in Translation. In M. SalamaCarr, Translating and interpreting conflict (pp. 135-147). Amsterdam-New York: Rodopi B.V.

The List Project to Ressetle Iraqi Allies. Organisation website http://thelistproject.org/.

The United Nations Office for Disaster Risk Reduction. Website https://www.unisdr.org/who-we-are.

The Young Iraqi Translator who Gave his Life for the American Effort. (2013). The Take Away. Retrieved from http://www.thetakeaway.org/story/274988carrying-iraq-us-story-one-iraqi-translator-who-gave-his-life-us-effort/ (accessed 6 June 2015).

TORDEN LLC. Business website http://www.torden.com/join-us/job-posting-afghaninterpreter-afghanistan/.

U.S. Army. Website http://www.goarmy.com/careers-and-jobs/browse-career-and-jobcategories/intelligence-and-combat-support/interpreter-translator.html. 